\author{
Mirosław Karpiuk \\ Uniwersytet Warmińsko-Mazurski w Olsztynie, Polska \\ ORCID: 0000-0001-7012-8999 \\ miroslaw.karpiuk@uwm.edu.pl
}

Tomasz Włodek

ORCID: 0000-0002-5236-7440

\title{
Wygaśnięcie mandatu wójta na skutek skazania na karę grzywny za niedopełnienie obowiązków z zakresu zarządzania kryzysowego. Glosa do wyroku Sądu Rejonowego w P. z dnia 18 kwietnia 2019 r. (II K 1164/14)
}

The Expiry of the Mandate of the Vogt Due to Being Fined for Non-compliance with the Obligation of Crisis Management. Gloss to the Judgement of the District Court in P. of 18 April 2019 (II K 1164/14)

\section{STRESZCZENIE}

Zadania z zakresu bezpieczeństwa i porządku publicznego, a także ochrony przeciwpowodziowej zostały przyznane przez ustawodawcę m.in. organowi wykonawczemu samorządu gminnego. Same normy zadaniowe nie mogą jednak stanowić dostatecznej podstawy prawnej dla ustalenia obowiązków organu w tym zakresie, zwłaszcza w aspekcie prawnokarnej oceny ich niedopełnienia. Taka ocena wymaga bowiem precyzyjnego ustalenia treści norm kompetencyjnych, gdyż dopiero takie normy statuują obowiązki organu i stanowią instrument realizacji zadań. Ustawodawca powinien wyraźnie wskazać, jakie obowiązki ciążą na organie, a sąd karny - określić te z nich, które zostały niedopełnione, z jednoczesnym podaniem konkretnego przepisu prawa zobowiązującego do określonego działania.

Słowa kluczowe: wygaśnięcie mandatu wójta; niedopełnienie obowiązków; zarządzanie kryzysowe; powódź

Sąd Rejonowy w P. uznał oskarżonego K.B. za winnego tego, że w dniu 30 maja 2014 r. w P., będąc funkcjonariuszem publicznym - wójtem gminy P., nie dopełnił ciążących na nim: 
- z mocy art. 31a ustawy o samorządzie gminnym z dnia 8 marca $1990 \mathrm{r}$. obowiązków podejmowania działań profilaktycznych w celu zapobieżenia skutkom powodzi,

- z mocy art. 19 ust. 2 ustawy o zarządzaniu kryzysowym z dnia 26 kwietnia 2007 r. obowiązków kierowania, monitorowania, planowania, reagowania i usuwania skutków zagrożeń na terenie gminy,

w ten sposób, że zaniechał podjęcia działań zmierzających do zabezpieczenia niekontrolowanego wypływu wody rzeki K., działań likwidujących istniejące przesiąki i wyrwy grobli tej rzeki, skutkiem czego działał na szkodę interesu prywatnego właścicieli nieruchomości położonych na terenie miejscowości B. ... oraz właścicieli nieruchomości położonych na terenie miejscowości Ł..., w konsekwencji narażając ich nieruchomości na zalanie, a także na szkodę interesu publicznego, znajdującego wyraz w spowodowaniu nadmiernych koszów Gminy P. wynikających ze zbyt późno podjętej akcji przeciwpowodziowej, konieczności przyznania zasiłków celowych przez Gminny Ośrodek Pomocy Społecznej ..., tj. dokonania przestępstwa z art. $231 \S 1$ k.k. i za to na podstawie art. $231 \S 1$ k.k. przy zastosowaniu art. 37a k.k. sąd skazał oskarżonego K.B. na karę 200 (dwustu) stawek dziennych grzywny ...

Orzeczenia sądów rejonowych rzadko stanowią przedmiot zainteresowania nauki prawa. Jednakże komentowany wyrok zasługuje na uwagę z kilku powodów. Po pierwsze, wyrok ten ma charakter precedensowy, gdyż - w razie utrzymania go w mocy przez sąd odwoławczy - w dniu ogłoszenia wyroku tego sądu wygaśnie mandat wójta. Po drugie, wyrok ten stanowi wyraz zredukowania przez sąd kwestii odpowiedzialności karnej wójta za niedopełnienie obowiązków wynikających z prawa administracyjnego wyłącznie do kategorii prawa karnego - sąd w danej sprawie zachował się tak, jak gdyby stosował tylko prawo karne, pomijając aspekty prawno-administracyjne i ustrojowe. Po trzecie zaś, na kanwie tej sprawy wyraźnie widać, że w dziedzinie zarządzania kryzysowego panuje chaos legislacyjny. Polega on m.in. na tym, że regulacje ustawowe opierają się na rozwiązaniach fasadowych (wydrążonych z treści normatywnej), które określają bogaty katalog zadań organów władzy publicznej, nie przyznając im środków umożliwiających ich realizację. Ponadto określenie obowiązków i form działania tych organów następuje w rozmaitych dokumentach planistycznych, choć kwestie te powinny być uregulowane w aktach normatywnych powszechnie obowiązujących.

$\mathrm{Na}$ kanwie analizy uzasadnienia wyroku zarysowuje się następujący stan faktyczny. W dniu 30 maja 2014 r. A.W. około godz. 6.00 spostrzegł, że doszło do zalania okolicznych pól przez wodę z rzeki K. Następnie - w godzinach porannych - A.W. zadzwonił do Urzędu Gminy P., informując o potrzebie podjęcia akcji 
ratowniczej. Około godz. 9.00 na miejsce zdarzenia przybył K.B. z pracownikami. Około godz. 10.00 A.K. poinformowała Państwową Straż Pożarną o przelewaniu rzeki. Otrzymała ona informację zwrotną, że PSP - aby podjąć działania ratownicze - musi otrzymać zgłoszenie od wójta. Bezpośrednio po tym A.K. powiadomiła wójta K.B. o rozmowie z PSP. A.D. około godz. 21.30 dokonała zgłoszenia do PSP, na skutek czego PSP podjęła działania ratownicze. W tym czasie K.B. powiadomił zastępy OSP w Ł. i B. o potrzebie przyłączenia się do akcji ratowniczej. Około godz. 23.00 K.B. wydał polecenie dostarczenia z gminnego magazynu przeciwpowodziowego worków na piach oraz piachu.

W dniu 13 lutego 2019 r. weszła w życie ustawa z dnia 31 stycznia 2019 r. o zmianie ustawy - Kodeks wyborczy (dalej: nowela). Istotną nowością jest to, że nowela nadaje nowe brzmienie art. 11 § 2 pkt 1 w zw. z art. 492 § 1 pkt 4 Kodeksu wyborczego (dalej: k.w.) w ten sposób, że rozszerza dotychczasowy zakres przesłanki wygaśnięcia mandatu wójta w postaci skazania prawomocnym wyrokiem sądu na karę pozbawienia wolności za umyślne przestępstwo ścigane z oskarżenia publicznego na każdą sytuację skazania prawomocnym wyrokiem sądu za umyślne przestępstwo ścigane z oskarżenia publicznego, w tym na sytuację skazania na karę grzywny. Zgodnie z art. 4 noweli nie ma przy tym znaczenia, czy dane przestępstwo zostało popełnione przed dniem 13 lutego 2019 r. czy też od tej daty. Przepis ten bowiem uzależnia wystąpienie skutku w postaci wygaśnięcia mandatu wójta od daty skazania na karę inną niż kara pozbawienia wolności - jeżeli skazanie na taką karę nastąpiło przed dniem 13 lutego 2019 r., to mandat nie wygasa, jeżeli zaś skazanie nastąpiło po tej dacie, wówczas mandat wygasa.

Czyn, za który wójt K.B. został skazany na karę grzywny komentowanym wyrokiem miał miejsce 30 maja 2014 r. Wyrok wydano w dniu 18 kwietnia 2019 r. Wyrok skutkuje zatem dla K.B. sankcją pozakodeksową w postaci wygaśnięcia mandatu wójta. Przy tym - zgodnie z art. 492a k.w. (w brzmieniu obowiązującym od 13 lutego 2019 r.) - sankcja ta następuje ex lege, nie istnieje żadna droga uchylenia się od tego skutku, w szczególności k.w. nie przewiduje możliwości zaskarżenia informacji komisarza wyborczego, o której mowa w tym przepisie.

Istnieje poważna wątpliwość, czy art. $492 \S 1$ pkt $4 \mathrm{w} \mathrm{zw} . \mathrm{z}$ art. $11 \S 2$ pkt 1 w zw. z art. 492a k.w. (w brzmieniu obowiązującym od dnia 13 lutego 2019 r.) w zw. $\mathrm{z}$ art. 4 noweli jest zgodny $\mathrm{z}$ art. 2 (zasada lex retro non agit, zasada odpowiednio długiej vacatio legis), art. 31 ust. 2 (zasada proporcjonalności), art. 42 ust. 1 (zasada nulla poena sine lege) Konstytucji RP. Na kanwie danej sprawy należy podkreślić, że kwestionowane przepisy mają charakter represyjny - nakładają na K.B. sankcję w postaci wygaśnięcia mandatu za czyn, który popełnił przed datą ustanowienia tej sankcji. Taka regulacja obraża elementarną zasadę prawa karnego nulla poena sine lege anteriori, jak też zakaz retroaktywności prawa. Kuriozalne jest również różnicowanie sytuacji prawnej podmiotów zależnie od daty skazania (zob. art. 4 noweli), a nie od daty popełnienia czynu. Oznacza to, że gdyby K.B. został skazany 
przed dniem 13 lutego 2019 r., to jego mandat by nie wygasł. Wydaje się, że sąd orzekający powinien był wziąć pod rozwagę tę okoliczność, wyznaczając termin rozprawy, na której zapadł wyrok. Chociaż z drugiej strony przyznać trzeba, że nowela nie zawiera żadnej vacatio legis (weszła w życie następnego dnia po dniu ogłoszenia). Zważywszy, że nowela w interesującym nas zakresie ma charakter represyjny, vacatio legis powinna być odpowiednio długa. Poważne wątpliwości odnośnie do konstytucyjności wskazanych zmian były podnoszone przez ekspertów w toku prac nad nowelą ${ }^{1}$. Na marginesie warto dodać, że art. 4 noweli stoi w kolizji z art. $4 \S 1$ ustawy z dnia 6 czerwca 1997 r. - Kodeks karny (dalej: k.k.), który ustanawia zasadę stosowania ustawy względniejszej dla sprawcy.

Trybunał Konstytucyjny wielokrotnie wskazywał, że zasada proporcjonalności wymaga, by przyczyna decydująca o wygaśnięciu mandatu była na tyle poważna, aby zniweczenie wyników wyborów było dostatecznie usprawiedliwione potrzebą ochrony innej wartości konstytucyjnej².

Sankcja w postaci wygaśnięcia mandatu osób skazanych na karę ograniczenia wolności lub karę grzywny (a zatem gdy społeczna szkodliwość przypisanego im czynu nie jest znaczna) nie może być uznana - zarówno w realiach niniejszej sprawy, jak i co do zasady - jako adekwatna i odpowiadająca zasadzie proporcjonalności określonej w art. 31 ust. 3 Konstytucji RP. Trafnie wskazuje M. Chmaj, że intencją ustrojodawcy jest zapewnienie szerokiego kręgu kandydatów na funkcje publiczne, z którego wyłączone powinny być jedynie osoby skazane za cięższe przestępstwa, których popełnienie obiektywnie i niezaprzeczalnie wiąże się z utratą zaufania niezbędnego do pełnienia tych funkcji, a nie kandydaci, w przypadku których ich skazanie może się z różnych przyczyn w jakiś sposób rozmijać z osądem społecznym, w szczególności w przypadku nieznacznej społecznej szkodliwości czynu. Zgodnie z art. 99 ust. 3 Konstytucji RP wybraną do Sejmu lub do Senatu nie może być osoba skazana prawomocnym wyrokiem na karę pozbawienia wolności za przestępstwo umyślne ścigane z oskarżenia publicznego. Skoro zaś w wyborach do parlamentu obowiązuje wyżej wymieniona regulacja wynikająca z ustawy zasadniczej, to za zbyt daleko idącą należy uznać przyjętą regulację dotyczącą wyborów wójta, w świetle której wyłączone z możliwości kandydowania będą osoby skazane m.in. na karę grzywny³.

Sąd orzekający zupełnie pominął wskazany powyżej skutek wyroku, przez co naruszył art. 53 k.k. Wygaśnięcie mandatu wójta stanowi drastyczną dolegliwość, nieporównanie bardziej intensywną niż zapłata grzywny. Przede wszystkim sankcja ta powoduje utratę przez K.B. ponad czteroletniej perspektywy funkcjonowania

Zob. m.in. opinie B. Przywory oraz M. Chmaja, Druk Sejmowy nr 3163.

Zob. np. wyrok TK z dnia 18 marca 2017 r., K 8/07.

Zob. M. Chmaj, Ocena przepisów poselskiego projektu ustawy o zmianie ustawy - Kodeks wyborczy, Druk Sejmowy nr 3163. 
w życiu zawodowym i społecznym oraz utratę dobrego imienia i nieposzlakowanej opinii. Sąd nie uwzględnił także, że mimo oskarżenia i trwającego procesu mieszkańcy gminy P. ponownie wybrali K.B. na wójta w październiku 2018 r.

Sąd skazał K.B. za popełnienie czynu, którego znamiona sąd zdekodował z art. $231 \S 1$ k.k. w zw. z art. 31a ustawy z dnia 8 marca 1990 r. o samorządzie gminnym (dalej: u.s.g.) oraz w zw. z art. 19 ust. 2 pkt 1 ustawy z dnia 26 kwietnia 2007 r. o zarządzaniu kryzysowym (dalej: u.z.k.). Zgodnie z art. 31a u.s.g. wójt opracowuje plan operacyjny ochrony przed powodzią oraz ogłasza i odwołuje pogotowie $i$ alarm przeciwpowodziowy. Natomiast art. 19 ust. 2 pkt 1 u.z.k. stanowi, że do zadań wójta w sprawach zarządzania kryzysowego należy kierowanie monitorowaniem, planowaniem, reagowaniem i usuwaniem skutków zagrożeń na terenie gminy. Sąd dokonał błędnej wykładni tych przepisów oraz błędnie je zastosował.

Po pierwsze, sąd w sentencji wyroku dokonał generalizacji zadań określonych w art. 31a u.s.g. i wywiódł $z$ tego przepisu ogólne zadanie wójta polegające na „podejmowaniu działań profilaktycznych w celu zapobieżenia skutkom powodzi”. Tymczasem art. 31a u.s.g. jest dość precyzyjny - ustanawia trzy zadania wójta: 1) opracowanie planu operacyjnego ochrony przed powodzią; 2) ogłaszanie i odwoływanie pogotowia przeciwpowodziowego; 3) ogłaszanie lub odwoływanie alarmu przeciwpowodziowego. Sąd nie wskazał, którego z tych trzech zadań K.B. nie dopełnił. Na marginesie dodać wypada, że w chwili popełnienia czynu przeciwpowodziowy plan operacyjny obowiązywał w gminie P. Natomiast żaden przepis prawa powszechnie obowiązującego nie określa, kiedy i w jakich okolicznościach powinno zostać ogłoszone pogotowie lub alarm przeciwpowodziowy. Mamy zatem do czynienia z sytuacją, w której sąd karny zamiast dążyć do jednoznacznego językowo określenia znamion czynu zabronionego dokonał zabiegu odwrotnego - do opisu znamion czynu zabronionego w wyroku skazującym posłużył się wyrażeniem nieznanym ustawie: ,podejmowanie działań profilaktycznych w celu zapobieżenia skutkom powodzi". W ten sposób doszło do naruszenia zasady nullum crimen sine lege - nie jest bowiem jasne, za niedopełnienie jakiego obowiązku wyrażonego w ustawie K.B. został skazany. Ponadto art. 31a u.s.g. nie stanowi normy kompetencyjnej, a jedynie zadaniową. Oznacza to, że nie może stanowić samoistnej podstawy rekonstrukcji obowiązku, którego niedopełnienie ma skutkować sankcją karną.

Po drugie, sąd zdekodował obowiązek wójta $\mathrm{z}$ art. 19 ust. 2 pkt 1 u.z.k. W tym punkcie sentencji sąd dosłownie przytoczył brzmienie pkt 1 tego przepisu i wywiódł z niego, że do obowiązków wójta należy „kierowanie, monitorowanie, planowanie, reagowanie i usuwanie skutków zagrożeń na terenie gminy". Sąd pominął jednak istotną część normy wyrażonej w tym punkcie, tj. treść ust. 1 art. 19, który brzmi: „[...] do zadań wójta w sprawach zarządzania kryzysowego należy [...]”. Ewidentnie zatem art. 19 ust. 2 pkt 1 stanowi normę zadaniową, nie zaś normę kompetencyjną.

$\mathrm{Na}$ gruncie prawa publicznego starannie rozróżnia się obydwie kategorie. Powszechnie uznaje się, że normy zadaniowe nie są stosowane samoistnie. Oznacza 
to, że ich realizacja nie może nastąpić inaczej niż poprzez wykonanie norm kompetencyjnych ${ }^{4}$. Ponadto $\mathrm{z}$ określenia zadań nie wynika automatycznie zdolność organu do podejmowania określonych działań. Realizacja zadań następuje poprzez wykonywanie przyznanych organowi kompetencji. Przytoczenie samej tylko normy zadaniowej jest niewystarczające do ustalenia treści obowiązku prawnego oskarżonego, którego nie dopełnił. Konieczne jest ustalenie treści tego obowiązku na podstawie norm kompetencyjnych. Tymczasem sąd orzekający poprzestał jedynie na przytoczeniu normy zadaniowej (i to z pominięciem jej istotnej części). Sąd powinien był określić, jakich działań K.B. nie dopełnił, których obowiązek podjęcia był określony w normach kompetencyjnych (które ze swej natury muszą być zawarte w źródłach prawa powszechnie obowiązującego). Ponadto sąd stwierdził w sentencji, że niedopełnienie przez K.B. obowiązków, o których mowa w art. 31 u.s.g. oraz w art. 19 ust. 2 pkt 1 u.z.k., polegało na „zaniechaniu podjęcia działań zmierzających do zabezpieczenia niekontrolowanego wypływu rzeki K., działań likwidujących istniejące przesiąki i wyrwy grobli tej rzeki [...]", a kilka wersów dalej sąd pisze (implicite), że niedopełnienie to polegało na „zbyt późno podjętej akcji przeciwpowodziowej”. W konsekwencji trudno oprzeć się wrażeniu, że sentencja wyroku skazującego została skonstruowana w sposób niejednoznaczny i chaotyczny. Sąd nie podał nawet, które znamiona czynu zabronionego zostały wyczerpane spośród wyliczonych w art. 19 ust. 2 pkt 1 u.z.k.: kierowanie, monitorowanie, planowanie, reagowanie czy usuwanie skutków. Podobne wrażenie chaosu powstaje na kanwie lektury uzasadnienia wyroku. Nie sposób w nim doszukać się choćby próby ustalenia przez sąd podstawy prawnej obowiązków wójta określonych w normach kompetencyjnych, za których niedopełnienie sąd skazał K.B., a liczba tych obowiązków zdaniem sądu jest dość pokaźna. W uzasadnieniu sąd mówi o następujących obowiązkach: niepodjęcie działań zmierzających do zapobieżenia wycieku rzeki K.; nieterminowe zainicjowanie akcji ratowniczej; skierowanie pracowników służb gminnych do akcji, rozdysponowanie workami z piaskiem, niezlecenie („,brak impulsu”) Państwowej Straży Pożarnej podjęcia akcji ratowniczej, niepodjęcie w porę działań zmierzających do usunięcia wyrwy; „,istotne naruszenie obowiązków służbowych przejawiające się niedopełnieniem obowiązków przy kierowaniu i zarządzaniu akcją przeciwpowodziową oraz kierowaniem, monitorowaniem oraz planowaniem i reagowaniem na istniejące na terenie podległej mu gminy zagrożenia”. Ponadto sąd podniósł naruszenie „podstawowych obowiązków nałożonych na niego aktami prawnymi o charakterze ustawowym $[\ldots] "$.

Na marginesie trzeba wskazać, że mylnie sąd przyjął w sentencji, że zachowanie K.B. spowodowało nadmierne koszty w postaci „konieczności przyznania zasiłków

4 Zob. M. Matczak, Kompetencja, [w:] System prawa administracyjnego, red. M. Matczak, R. Hauser, Warszawa 2015, s. 429 i n. 
celowych przez Gminny Ośrodek Pomocy Społecznej w Puławach”. Nie istniała w tym zakresie żadna konieczność, gdyż podstawą prawną przyznania zasiłków celowych był art. 40 ustawy z dnia 12 marca 2004 r. o pomocy społecznej, który decyzję o przyznaniu takiego zasiłku pozostawia uznaniu administracyjnemu kierownika GOPS. Trudno tutaj mówić o konieczności w sensie prawnym, skoro kierownik GOPS mógł w zasadzie w każdym wypadku takiej pomocy odmówić. Tym bardziej, że w danej sprawie nie mamy do czynienia z klęską żywiołową ani ze szkodami w budynkach mieszkalnych, a jedynie na gruntach rolnych.

W zaskarżonym wyroku sąd zupełnie pominął obowiązki (kompetencje) Państwowej Straży Pożarnej (dalej: PSP) w zakresie prowadzenia działań w sytuacji zagrożenia powodziowego. Tymczasem cały system organizacyjno-kompetencyjny w tym zakresie jest oparty na tej właśnie formacji. System ten tworzą: 1) ustawa z dnia 24 sierpnia 1991 r. o ochronie przeciwpożarowej (dalej: u.o.ppoż.) wraz z aktami wykonawczymi do niej, którymi są m.in.: a) rozporządzenie Ministra Spraw Wewnętrznych i Administracji z dnia 18 lutego 2011 r. w sprawie szczegółowych zasad organizacji Krajowego Systemu Ratowniczo-Gaśniczego, b) rozporządzenie Ministra Spraw Wewnętrznych i Administracji z dnia 31 lipca 2001 r. w sprawie szczegółowych zasad kierowania i współdziałania jednostek ochrony przeciwpożarowej biorących udział w działaniu ratowniczym; 2) ustawa z dnia 24 sierpnia 1991 r. o Państwowej Straży Pożarnej (dalej: u.PSP); 3) ustawa z dnia 26 kwietnia 2007 r. o zarządzaniu kryzysowym.

Zasadniczy układ organizacyjno-kompetencyjny w zakresie działań przeciwpowodziowych został utworzony w $1991 \mathrm{r}$. na skutek wejścia w życie u.o.ppoż. oraz u.PSP. Warto w tym miejscu zaznaczyć, że tytuł u.o.ppoż. jest mylący, sugeruje bowiem, że jej zakres obejmuje tylko kwestie pożarowe. W istocie jednak zakres tej ustawy wyznacza art. 1, zgodnie z którym ochrona przeciwpożarowa polega na realizacji przedsięwzięć mających na celu ochronę życia, zdrowia, mienia lub środowiska przed pożarem, klęską żywiołową lub innym zagrożeniem miejscowym.

Bez wątpienia sytuacja z dnia 30 maja 2014 r. stanowiła zagrożenie miejscowe, którego legalną definicję zawiera art. 2 pkt 3 u.o.ppoż., zgodnie z którym zagrożenie miejscowe to m.in. zdarzenie wynikające $\mathrm{z}$ naturalnych praw przyrody, niebędące pożarem ani klęską żywiołową, stanowiące zagrożenie dla życia, zdrowia, mienia lub środowiska, któremu zapobieżenie lub usunięcie skutków nie wymaga zastosowania nadzwyczajnych środków. Zgodnie z art. $22 \mathrm{w}$ zw. z art. 2 pkt 2 u.o.ppoż. w sytuacji zagrożenia miejscowego obowiązek podjęcia i prowadzenia działań ratowniczych mają jednostki ochrony przeciwpożarowej, o których mowa w art. 15 pkt 1-6 i 8 u.o.ppoż., w tym przede wszystkim jednostki PSP, a także ochotnicza straż pożarna. Wśród tych podmiotów nie ma wójta. Zgodnie z art. 2 pkt 2 i 3 u.o.ppoż. działanie ratownicze to każda czynność podjęta w celu ochrony życia, zdrowia, mienia lub środowiska, a także likwidacja przyczyn powstania miejscowego zagrożenia. 
Należy wskazać, że na terenie gminy P. działa 11 Ochotniczych Straży Pożarnych, przy czym każda z nich jest oddzielnym stowarzyszeniem (zgodnie z art. 19 u.o.ppoż.), a jednocześnie są one członkami stowarzyszenia - Związku OSP RP. Związek ten posiada w gminie P. swój oddział gminny, którego prezesem jest wójt K.B. Status K.B. jako prezesa określa statut Związku - obejmuje on wyłącznie uprawnienia reprezentacyjno-organizacyjne, prezes nie ma żadnych statutowych uprawnień kierowniczych czy związanych z dysponowaniem OSP. Zatem K.B. w sensie prawnym nie ma uprawnień władczych wobec OSP, które zobowiązywałyby OSP do podjęcia działań. W dniu 30 maja 2014 r. obowiązywał statut z 2008 r.

$\mathrm{W}$ danej sprawie istotne jest, że dwie OSP (w miejscowościach G.P. i G.) należą do Krajowego Systemu Ratowniczo-Gaśniczego (dalej: ksrg). Oznacza to m.in., że podlegają one bezpośredniemu kierownictwu komendanta powiatowego PSP w P., który może te jednostki dysponować (bez żadnego udziału wójta) ${ }^{5}$. Wprawdzie art. 14 ust. 5 u.o.ppoż. stanowi o tym, że wójt koordynuje funkcjonowanie ksrg na terenie gminy w zakresie ustalonym przez wojewodę, jednakże jest to przepis martwy, gdyż: 1) wójt nie ma żadnych kompetencji pozwalających na zrealizowanie koordynacji; 2) wojewoda na dzień 30 maja 2014 r. nie ustalił zakresu, o którym mowa w tym przepisie; 3) koordynowanie jest bez porównania słabszą relacją niż prawo do kierowania i dysponowania sił i środków ksrg do działań ratowniczych, do czego kompetencje ma komendant PSP poprzez stanowisko kierowania w Komendzie PSP (art. 13 ust. 6 pkt 4 u.PSP). Art. 20 ust. 1 w zw. z art. 13 ust. 6 pkt 7 u.PSP stanowi, że to komendant powiatowy PSP organizuje i kieruje akcją ratowniczą, czyli działaniami ratowniczymi.

Sąd nie odniósł się też w żadnej mierze do art. 14 ust. 3-8 u.PSP. Zgodnie z nim w przypadku bezpośredniego zagrożenia bezpieczeństwa wspólnoty samorządowej, w szczególności życia lub zdrowia, wójt może wydać komendantowi powiatowemu PSP polecenie podjęcia działań w zakresie właściwości PSP zmierzających do usunięcia tego zagrożenia. Zgodnie z art. 14 ust. 4 u.PSP polecenie takie nie może dotyczyć wykonania konkretnej czynności służbowej ani określać sposobu wykonania zadania przez PSP. Ponadto wójt ponosi wyłączną odpowiedzialność za treść i skutki takiego polecenia (art. 14 ust. 5 u.PSP). W danej sprawie sąd winien był uwzględnić ten przepis i zbadać, czy sytuacja z dnia 30 maja 2014 r. mogła stanowić podstawę do wydania przez K.B. polecenia. Należy bowiem przyjąć, że przepis ten może być stosowany tylko w sytuacji kwalifikowanego zagrożenia bezpieczeństwa, tj. takiego, które ma charakter szczególny, bezpośredni i dotyka przede wszystkim życia i zdrowia. W danej sytuacji mieliśmy do czynienia z wylaniem małej rzeki na pola, z których część to ugory. W zasadzie nie wystąpiło nawet zagrożenie dla budynków mieszkalnych, a z pewnością zagrożenie to nie było bezpośrednie. Należy przy tym podkreślić, że z żadnego przepisu prawa

\footnotetext{
5 Zob. art. 13 ust. 6 pkt 4 u.PSP.
} 
nie wynika, aby do podjęcia działań ratowniczych przez PSP wymagane było polecenie wójta.

Dla pełnego obrazu organizacji systemu przeciwpowodziowego należy dodać, że w 2007 r. został on uzupełniony o u.z.k. ${ }^{6}$ Ustawa ta stanowi nowość normatywną, gdyż reguluje kwestie dotychczas nieregulowane (nie zawiera żadnych przepisów derogacyjnych). Ponadto ustawa ta nie modyfikuje w żaden sposób ani u.o.ppoż., ani u.PSP (poza ustanowieniem zespołów zarządzania kryzysowego). Można przyjąć, że stanowi ona swego rodzaju ustawę ramową, ,nakładkę normatywną" na układ organizacyjno-kompetencyjny utworzony w $1991 \mathrm{r}$. na podstawie u.o.ppoż. i u.PSP, pozostawiając niezmienione dotychczasowe zadania i kompetencje PSP. Oznacza to przede wszystkim, że u.z.k. tworzy całość normatywną z u.o.ppoż. oraz u.PSP, zatem interpretacja przepisów u.z.k. wymaga w zasadzie zawsze odniesienia się do tych ustaw. Wynika to m.in. $\mathrm{z}$ faktu, że u.z.k. zawiera wiele norm zadaniowych, a jeżeli już ustanawia normy kompetencyjne, to z reguły mają one charakter przepisów zrębowych niezupełnych, co oznacza, że do rekonstrukcji z nich pełnej normy prawnej konieczne jest sięgnięcie do innych aktów normatywnych.

W interesującym nas zakresie należy wskazać, że u.z.k. nakłada na wójta m.in. zadanie w postaci opracowania i przedłożenia staroście do zatwierdzenia gminnego planu zarządzania kryzysowego (art. 19 ust. 2 pkt 2 u.z.k.), który powinien zawierać m.in. określenie zadań i obowiązków uczestników zarządzania kryzysowego (art. 5 ust. 2 pkt 1 lit. b u.z.k.). Plan taki obowiązywał w dniu 30 maja 2014 r. - został opracowany przez K.B. i zatwierdzony przez starostę. Należy podkreślić, że ma on formę zarządzenia wójta, które nie stanowi aktu prawa miejscowego.

Konstruując obowiązek K.B. stanowiący element czynu zabronionego, sąd ograniczył się tylko do art. 19 ust. 2 pkt 1 u.z.k. oraz art. 31a u.s.g. W żadnym miejscu uzasadnienia sąd nawet nie wspomniał o zadaniach i kompetencjach PSP. Tymczasem ustalenie, czy PSP miała obowiązek działać w danej sytuacji oraz kiedy ten obowiązek się zaktualizował, ma kluczowe znaczenie dla oceny stopnia winy K.B. W toku postępowania ustalono bowiem, że w dniu 30 maja 2014 r. około godz. 11 mieszkanka gminy A.K. powiadomiła dyżurnego PSP w P. o przelewaniu się wody z rzeki K. na okoliczne pola. Niezwłocznie po tym zadzwoniła ona do K.B. i poinformowała go m.in. o tym, że powiadomiła PSP w P. Wobec tego od chwili powzięcia tej informacji K.B. miał uzasadnione prawo oczekiwać, że PSP podejmie działania ratownicze zgodnie ze swoimi obowiązkami (kompetencjami). PSP podjęła te działania jednak dopiero o godz. $21.23 \mathrm{w}$ związku ze zgłoszeniem - tym razem dokonanym przez A.D.

Tymczasem sąd w sposób nieuzasadniony przyjął jako własny pogląd wyrażony w postępowaniu przez biegłego J.K. oraz świadka K.M. (funkcjonariusza PSP w P.), jakoby koniecznym warunkiem podjęcia akcji ratowniczej przez PSP było

\footnotetext{
${ }^{6}$ Zob. tekst pierwotny Dz.U. nr 89, poz. 590.
} 
zlecenie (,impuls”) ze strony wójta K.B. W braku takiego zlecenia PSP opóźniła swoje działania. Przy tym świadek K.M. zeznał, jakoby PSP mogła działać bez zlecenia wójta tylko w razie zagrożenia życia lub zdrowia, a w sytuacji zagrożenia samego tylko mienia - nie. Takie twierdzenie - uznane przez sąd - nie znajduje żadnych podstaw prawnych. Sąd winien był ustalić tę podstawę prawną zamiast bezkrytycznie dawać wiarę świadkowi.

W danej sprawie - poza kwestią odpowiedzialności wójta - powstaje także kwestia odpowiedzialności PSP za opóźnienie podjęcia działań ratowniczych, które to opóźnienie nie znajduje żadnego usprawiedliwienia w przepisach prawa. Skoro K.B. na podstawie ogólnikowych norm zadaniowych zdaniem sądu miał obowiązek podjąć działania niezwłocznie po godz. 9.00, to dlaczego PSP - mająca obowiązek ich podjęcia-zwlekała od godz. 11 (pierwsze zgłoszenie) do 21.23? Sąd winien był uwzględnić tę okoliczność przy ocenie dowodu z zeznań świadków (strażaków z PSP w P.) jako bezpośrednio zainteresowanych obarczeniem K.B. całą winą za opóźnienie akcji. Poważną wątpliwość odnośnie do rzetelności opinii biegłego J.K. (którą sąd przyjął jako dowód pewny) budzi twierdzenie, jakoby dopiero telefon A.D. o godz. 21.23 wykonany do komendanta PSP w P. stanowił formalne zgłoszenie do PSP. Oznacza to, że zgłoszenie A.K. z około godz. 11.00 do dyżurnego nie zostało przez PSP uznane za formalnie dokonane (skuteczne). Sąd winien był wyjaśnić tę okoliczność, ponieważ sugeruje ona, że PSP nie udokumentowała należycie zgłoszenia dokonanego na numer alarmowy, a za należycie dokonane uznaje „telefon do komendanta”.

Prawodawca w art. 19 ust. 2 pkt 1 u.z.k. wyraźnie stwierdza, że do zadań wójta, burmistrza, prezydenta miasta w sprawach zarządzania kryzysowego należy kierowanie monitorowaniem, planowaniem, reagowaniem i usuwaniem skutków zagrożeń na terenie gminy ${ }^{7}$. Ustawodawca $w$ tym przepisie kreuje zatem normę zadaniową, a nie kompetencyjną, wprost stanowiąc: „Do zadań wójta, burmistrza, prezydenta miasta w sprawach zarządzania kryzysowego należy [...]”. Art. 19 ust. 2 pkt 1 nie nakłada zatem na organ wykonawczy gminy żadnych obowiązków, lecz określa jego zadania, które muszą być następnie przez ustawodawcę skonkretyzowane poprzez przyznanie mu określonych kompetencji w tym zakresie.

Art. 19 ust. 2 u.z.k. nie rozstrzyga, w jakich formach prawnych organ gminy będzie realizował sprawy wskazane w tym przepisie oraz jakie będzie podejmował czynności faktyczne ${ }^{8}$.

Naczelną zasadą prawa administracyjnego jest zakaz domniemania kompetencji. Należy podkreślić, że normy upoważniające powinny być interpretowane w sposób

7 Art. 19 ust. 2 u.z.k. określa zadania wójta, burmistrza, prezydenta miasta. Zob. M. Karpiuk, Miejsce samorzadu terytorialnego w przestrzeni bezpieczeństwa narodowego, Warszawa 2014, s. 171.

8 M. Czuryk, K. Dunaj, M. Karpiuk, K. Prokop, Prawo zarzadzania kryzysowego. Zarys systemu, Olsztyn 2016, s. 93. 
ścisły, literalny9 . Podstawą władczego działania organu administracji publicznej może być wyłącznie kompletna norma materialna, determinująca wszystkie elementy stosunku administracyjnoprawnego, w tym określająca kompetencje (zdolność, możność) organu administracji publicznej do autorytatywnego zastosowania określonej normy prawa przedmiotowego ${ }^{10}$.

Zgodnie z zasadą praworządności organom władzy publicznej wolno tylko tyle, na ile pozwalają przepisy prawa. Organy władzy publicznej nie mogą domniemywać swoich kompetencji. Kompetencje organów muszą jasno oraz jednoznacznie wynikać z przepisów ustaw ${ }^{11}$. Wystąpienie jakichkolwiek wątpliwości co do istnienia danej kompetencji powinno być równoznaczne ze stwierdzeniem jej braku ${ }^{12}$. W praworządnym państwie nie jest możliwe utożsamianie zadań i kompetencji ${ }^{13}$.

Normy o charakterze zadaniowym, a nie kompetencyjnym, same w sobie nie mogą być podstawą żadnych działań władczych organu gminy ${ }^{14}$. Wskazanie przez ustawodawcę na określonego rodzaju zadanie gminy nie jest tożsame z wyposażeniem organu tej gminy w możliwość określenia formy realizacji takiego zadania. Zadania gminy nie mogą być utożsamiane z kompetencjami; jedynie kompetencja stwarza potencjalną możliwość ważnego dokonania przez organ czynności konwencjonalnej. Nie można utożsamiać ze sobą norm o zadaniach i norm określających kompetencje do działań władczych ${ }^{15}$.

W sensie ustrojowego prawa administracyjnego termin „kompetencje” oznacza zespół normatywnie określonych praw, a zarazem obowiązków organu administracji publicznej, z jednoczesnym wskazaniem na określone formy działania organu ${ }^{16}$.

Norma kompetencyjna stanowi upoważnienie organu władzy publicznej do dokonania czynności konwencjonalnej doniosłej prawnie. Skorzystanie przez organ z tego upoważnienia rodzi po stronie określonego podmiotu obowiązek określonego zachowania się. Upoważnienie może mieć charakter fakultatywny lub obligatoryjny. W pierwszym przypadku organowi pozostawia się swobodę w określeniu sytuacji prawnej podmiotu prawa, w drugim zaś organ zobowiązany będzie skorzystać z kompetencji ${ }^{17}$.

${ }^{9}$ Wyrok WSA z dnia 14 listopada 2018 r., II SA/Go 713/18, LEX nr 2582085.

10 Wyrok NSA z dnia 21 sierpnia 2018 r., I GSK 2276/18, LEX nr 2558172.

11 Wyrok WSA z dnia 24 października 2017 r., III SA/Kr 397/17, LEX nr 2381414.

12 Wyrok WSA z dnia 13 kwietnia 2017 r., II SA/Gl 124/17, LEX nr 2278648.

13 Wyrok WSA z dnia 18 listopada 2009 r., IV SA/G1 327/09, LEX nr 589404. W przedmiocie zasady demokratycznego państwa prawnego zob. szerzej: M. Bożek, M. Karpiuk, J. Kostrubiec, K. Walczuk, Zasady ustroju politycznego państwa, Poznań 2012, s. 87-102.

${ }_{14}$ Wyrok WSA z dnia 16 lipca 2014 r., IV SA/Po 507/14, LEX nr 1498465.

15 Wyrok WSA z dnia 9 października 2008 r., II SA/Rz 506/08, LEX nr 505412.

16 J. Dobkowski, Kompetencja administracyjna, „Studia z Zakresu Nauk Prawnoustrojowych. Miscellanea” 2008, nr 1, s. 111.

${ }^{17}$ K. Dunaj, K. Prokop, Prawoznawstwo. Zagadnienia podstawowe, Warszawa 2017, s. 70-71. 
Kreowanie obowiązku ciążącego na organie wykonawczym gminy na podstawie art. 19 ust. 2 pkt 1 u.z.k. zawierającego normę zadaniową narusza zasadę praworządności wyrażoną w art. 7 Konstytucji RP, ponieważ już sam ustawodawca wyraźnie stanowi, że przepis ten określa zadania wójta (burmistrza, prezydenta miasta), a nie jego obowiązki, których nie należy domniemywać, gdyż mogą one wynikać tylko z norm kompetencyjnych, a nie z norm zadaniowych.

Ustawodawca w art. 31a u.s.g. wskazuje, że wójt opracowuje plan operacyjny ochrony przed powodzią oraz ogłasza i odwołuje pogotowie $i$ alarm przeciwpowodziowy, nie określa jednak, jakie okoliczności determinują podjęcie takich działań (np. w sytuacji kryzysowej bądź gdy powódź zagraża mieniu w znacznych rozmiarach czy zdrowiu i życiu ludzi), oraz nie wymienia (nawet przykładowo), w jakich okolicznościach podejmuje takie działania, zostawiając to uznaniu administracyjnemu. Norma $z$ art. 31 a u.s.g. (podobnie jak z art. 19 ust. 2 pkt 1 u.z.k.) jest normą ogólną, z której nie wynikają wprost określone obowiązki organu wykonawczego gminy w zakresie w niej wskazanym. Ustawodawca w art. 31a u.s.g. nie określa, kiedy zagrożenie, jakim jest powódź, determinuje ogłoszenie pogotowia i alarmu przeciwpowodziowego, w związku z powyższym pociągnięcie do odpowiedzialności karnej na podstawie tak ogólnego przepisu wydaje się być zabiegiem chybionym. Jest to wręcz niemożliwe w sytuacji, gdy określone zadania w tym obszarze zostały przez organ wykonawczy podstawowej jednostki samorządu terytorialnego podjęte. Pozostawienie przez ustawodawcę organowi administracji publicznej swobody w zakresie realizowania tego rodzaju zadań powoduje, że ocena ich wykonania musi również bazować na tym uznaniu. Trudno zatem stawiać zarzut braku reakcji na zagrożenie wójtowi, gdy ten podjął określone działania, według niego konieczne w sytuacji występującego zagrożenia, gdy te jednak - w przypadku subiektywnej oceny innych - podjęte być powinny w inny sposób bądź w innym czasie.

Organ administracji publicznej (w tym przypadku organ gminy), ogłaszając pogotowie i alarm przeciwpowodziowy, wkracza w sferę konstytucyjnych praw i wolności jednostki, w związku z czym ingerencja taka obwarowana jest kilkoma warunkami, które określa art. 31 ust. 3 Konstytucji RP. Według tego przepisu ograniczenia $\mathrm{w}$ zakresie korzystania $\mathrm{z}$ konstytucyjnych wolności i praw mogą być ustanawiane tylko w ustawie i tylko wtedy, gdy są konieczne w demokratycznym państwie dla jego bezpieczeństwa lub porządku publicznego bądź dla ochrony środowiska, zdrowia i moralności publicznej albo wolności i praw innych osób. Ograniczenia te nie mogą naruszać istoty wolności i praw ${ }^{18}$. W związku z tym wójt nie działa na polecenie mieszkańców czy w związku z telefonem jednego z nich, a gdy jest to konieczne, czyli gdy w inny sposób nie uda się uniknąć zagrożenia.

${ }^{18}$ Zob. szerzej: M. Karpiuk, K. Prokop, P. Sobczyk, Ograniczenie korzystania z wolności i praw człowieka i obywatela ze względu na bezpieczeństwo państwa i porządek publiczny, Siedlce 2017, s. 23-36. 
Działania ingerencyjne podejmowane są więc w ostateczności, „gdy są konieczne w demokratycznym państwie dla jego bezpieczeństwa [...]".

Norma $\mathrm{z}$ art. 31a u.s.g. ma charakter zadaniowy, a nie kompetencyjny, zatem trudno tylko na jej podstawie wywieść określone obowiązki wójta. Może ona stanowić swoiste uzupełnienie innej normy prawa materialnego kreującej obowiązek organu administracji publicznej, lecz nie samoistną podstawę, z której rzekomo taki obowiązek wynika. Abstrahując nawet od jej charakteru, działania w niej przewidziane mogą być podjęte wyłącznie w przypadku, gdy nie da się w inny sposób zapewnić bezpieczeństwa (jeżeli jest to konieczne, w ostateczności, gdy nie ma innego wyjścia) i proporcjonalnie do zagrożenia, gdyż ogłoszenie pogotowia i alarmu przeciwpowodziowego może ograniczać prawa i wolności jednostki.

Ustawodawca wyraźnie przewiduje, że kto zauważy pożar, klęskę żywiołową lub inne miejscowe zagrożenie, ma obowiązek niezwłocznie zawiadomić osoby znajdujące się w strefie zagrożenia oraz centrum powiadamiania ratunkowego lub jednostkę ochrony przeciwpożarowej albo Policję bądź wójta albo sołtysa. Obowiązek ten wynika $\mathrm{z}$ art. 9 u.o.ppoż. W związku z powyższym, jak wynika z art. 9 u.o.ppoż., dla podjęcia działań zaradczych skierowanych przeciwko miejscowemu zagrożeniu wystarczy zawiadomienie któregokolwiek z organów wymienionych w tym przepisie, a już na pewno na podstawie zgłoszenia skierowanego bezpośrednio do jednostki ochrony przeciwpożarowej podmiot ten jest uprawniony (a nawet zobowiązany) do podjęcia określonych działań w zakresie zapewnienia bezpieczeństwa bez konieczności czekania na jakikolwiek sygnał (zawiadomienie, zgodę, opinię) innych organów wymienionych w art. 9 u.o.ppoż., w tym wójta (burmistrza, prezydenta miasta).

$\mathrm{W}$ art. 9 u.o.ppoż. ustawodawca posługuje się pojęciem ,innego miejscowego zagrożenia", na które ma reagować jednostka ochrony przeciwpożarowej, a które jest $\mathrm{w}$ art. 2 pkt 3 u.o.ppoż. definiowane jako zdarzenie wynikające z rozwoju cywilizacyjnego i naturalnych praw przyrody, niebędące pożarem ani klęską żywiołową, stanowiące zagrożenie dla życia, zdrowia, mienia lub środowiska, któremu zapobieżenie lub którego usunięcie skutków nie wymaga zastosowania nadzwyczajnych środków. Powódź odpowiada zatem tej definicji. Z kolei jednostką ochrony przeciwpożarowej według art. 15 pkt 1 u.o.ppoż. są jednostki organizacyjne Państwowej Straży Pożarnej, w tym również te powiatowe.

Działanie ratownicze na podstawie art. 22 ust. 1 u.o.ppoż. prowadzą jednostki ochrony przeciwpożarowej, o których mowa w art. 15 pkt 1-6 i 8 u.o.ppoż., a nie organ wykonawczy samorządu gminnego.

Przekazywanie jednostkom ochrony przeciwpożarowej informacji o pożarach, klęskach żywiołowych i innych miejscowych zagrożeniach oraz koordynację i organizację prowadzenia działań ratowniczych zapewniają: 1) Krajowe Centrum Koordynacji Ratownictwa i Ochrony Ludności - w Komendzie Głównej Państwowej Straży Pożarnej; 2) wojewódzkie stanowisko koordynacji ratownictwa - w komen- 
dach wojewódzkich Państwowej Straży Pożarnej; 3) powiatowe (miejskie) stanowisko kierowania - w komendach powiatowych (miejskich) Państwowej Straży Pożarnej; 4) punkty alarmowania - w jednostkach ochrony przeciwpożarowej. Powyższy obowiązek informacyjny wynika z $§ 1$ rozporządzenia Ministra Spraw Wewnętrznych i Administracji z dnia 31 lipca 2001 r. w sprawie szczegółowych zasad kierowania i współdziałania jednostek ochrony przeciwpożarowej biorących udział w działaniu ratowniczym. Obowiązek ten na gruncie tego przepisu nie ciąży zatem na wójcie.

Wójt (burmistrz, prezydent miasta) jedynie koordynuje funkcjonowanie krajowego systemu ratowniczo-gaśniczego na obszarze gminy w zakresie ustalonym przez wojewodę, co wynika $\mathrm{z}$ art. 14 ust. 5 u.o.ppoż., natomiast na podstawie art. 22 ust. 1a u.o.ppoż. Państwowa Straż Pożarna posiada kompetencje kierownicze w zakresie działań ratowniczych. Kierownictwo to ustawowe upoważnienie do podejmowania wiążących czynności i aktów zawierających wytyczne lub polecenia. Podstawową cechą kierownictwa jest władztwo, które pozwala na determinowanie zachowań podwładnych niezależnie od ich woli. Z kolei koordynacja to zespół uprawnień w stosunku do podmiotów bezpośrednio niepodporządkowanych. Sprowadza się ona do harmonizacji działań różnych podmiotów dla osiągnięcia zamierzonych celów ${ }^{19}$. Decydujące znaczenie z punktu widzenia przeciwdziałania innym miejscowym zagrożeniom i ich skutkom ma więc kierownictwo, a nie koordynacja.

W przypadku bezpośredniego zagrożenia bezpieczeństwa ${ }^{20}$ wspólnoty samorządowej, w szczególności życia lub zdrowia, wójt (burmistrz, prezydent miasta) lub

${ }_{19}$ N. Szczęch, [w:] Administracja publiczna i prawo administracyjne w zarysie, red. M. Karpiuk, J. Kowalski, Warszawa-Poznań 2013, s. 21.

${ }^{20}$ W zakresie pojęcia bezpieczeństwa zob. szerzej: M. Karpiuk, Ubezpieczenie społeczne rolników jako element bezpieczeństwa społecznego. Aspekty prawne, „Międzynarodowe Studia Społeczno-Humanistyczne. Humanum" 2018, nr 2, s. 67-70; M. Czuryk, K. Dunaj, M. Karpiuk, K. Prokop, Bezpieczeństwo państwa. Zagadnienia prawne i administracyjne, Olsztyn 2016, s. 17-19; M. Karpiuk, Position of the Local Government of Commune Level in the Space of Security and Public Order, „Studia Iuridica Lublinensia” 2019, nr 2, DOI: https://doi.org/10.17951/sil.2019.28.2.27-39, s. 31; Aspekty prawne bezpieczeństwa narodowego RP. Część ogólna, red. W. Kitler, M. Czuryk, M. Karpiuk, Warszawa 2013, s. 11-45; M. Karpiuk, Konstytucyjna właściwość Sejmu w zakresie bezpieczeństwa państwa, „Studia Iuridica Lublinensia” 2017, nr 4, s. 10; M. Czuryk, K. Drabik, A. Pieczywok, Bezpieczeństwo człowieka $w$ procesie zmian społecznych, kulturowych i edukacyjnych, Olsztyn 2018, s. 7; A. Pieczywok, Działania społeczne w sferze bezpieczeństwa wewnętrznego, Lublin 2018, s. 109; M. Karpiuk, Ograniczenie wolności uzewnętrzniania wyznania ze względu na bezpieczeństwo państwa i porzadek publiczny, „Przegląd Prawa Wyznaniowego” 2017, t. 9, s. 10-17; M. Czuryk, J. Kostrubiec, The legal status of local self-government in the field of public security, „Studia nad Autorytaryzmem i Totalitaryzmem" 2019, nr 1, s. 33-47; M. Karpiuk, Position of County Government in the Security Space, „Internal Security” 2019, nr 1, DOI: https://doi.org/10.5604/01.3001.0013.5349, s. 148-151; M. Karpiuk, N. Szczęch, Bezpieczeństwo narodowe i międzynarodowe, Olsztyn 2017, s. 13-40; M. Karpiuk, Prezydent Rzeczypospolitej Polskiej jako organ stojący na straży bezpieczeństwa państwa, „Zeszyty Naukowe AON” 2009, nr 3, s. 389-390; M. Czuryk, Właściwość Rady Ministrów 
starosta może wydać komendantowi powiatowemu (miejskiemu) Państwowej Straży Pożarnej polecenie podjęcia działań w zakresie właściwości Państwowej Straży Pożarnej zmierzających do usunięcia tego zagrożenia. Kompetencje te wynikają $\mathrm{z}$ art. 14 ust. 3 u.PSP. Ustawodawca po stronie wójta (burmistrza, prezydenta miasta) kreuje jedynie uprawnienie, a nie obowiązek, o czym świadczy zwrot „może”. Ustawodawca celowo zrezygnował ze zwrotu kategorycznego „wydaje” polecenie na rzecz „może wydać” polecenie, ponieważ pomiędzy wójtem a komendantem powiatowym PSP nie występuje ani więź organizacyjna, ani więź funkcjonalna, ani więź służbowa. Z art. 14 ust. 3 u.PSP nie da się zdekodować obowiązku wójta. $\mathrm{Na}$ gruncie tego przepisu działa on $\mathrm{w}$ ramach uznania administracyjnego. Ponadto wydanie komendantowi powiatowemu (miejskiemu) Państwowej Straży Pożarnej przez organ wykonawczy gminy polecenia w zakresie podjęcia działań ratowniczych mieszczących się we właściwości Państwowej Straży Pożarnej zmierzających do usunięcia tego zagrożenia ma sens w przypadku, gdy straż nie ma takiej informacji. Gdy posiada ona informację o zagrożeniu bezpieczeństwa i czeka na polecenie innego organu (zewnętrznego, spoza struktury PSP, np. wójta), to nie wykonuje ona ustawowego obowiązku reagowania na zagrożenie miejscowe, jakim jest m.in. powódź (jako zagrożenie bezpieczeństwa), narusza więc prawo oraz naraża życie i zdrowie mieszkańców, a także mienie na szkody, które mogą powstać w wyniku powodzi.

Rozpoznawanie zagrożeń pożarowych i innych miejscowych zagrożeń oraz organizowanie i prowadzenie akcji ratowniczych w czasie pożarów, klęsk żywiołowych lub likwidacji miejscowych zagrożeń należy do podstawowych zadań Państwowej Straży Pożarnej, wynikających z art. 1 ust. 2 pkt 1-2 u.PSP, a zadania i kompetencje PSP na obszarze województwa na podstawie art. 11 u.PSP wykonują: 1) wojewoda przy pomocy komendanta wojewódzkiego Państwowej Straży Pożarnej jako kierownika straży wchodzącej w skład zespolonej administracji rządowej w województwie; 2) komendant powiatowy (miejski) Państwowej Straży Pożarnej.

oraz Prezesa Rady Ministrów w zakresie obronności, bezpieczeństwa i porządku publicznego, Olsztyn 2017, s. 9; M. Karpiuk, Właściwość wojewody w zakresie zapewnienia bezpieczeństwa i porzadku publicznego oraz zapobiegania zagrożeniu życia i zdrowia, „Zeszyty Naukowe KUL” 2018, nr 2, s. 227-228; D. Tyrawa, Gwarancje bezpieczeństwa osobistego w polskim administracyjnym prawie drogowym, Lublin 2018, s. 40-46; M. Karpiuk, Zadania administracji publicznej w zakresie bezpieczeństwa społecznego dotyczace wspierania rodziny przeżywajacej trudności $w$ wypetnianiu funkcji opiekuńczo-wychowawczych i odnoszace się do systemu pieczy zastępczej, „Społeczeństwo i Rodzina” 2018, nr 3, s. 54-55; M. Czuryk, Bezpieczeństwo jako dobro wspólne, „Zeszyty Naukowe KUL" 2018, nr 3, s. 15; W. Lis, Bezpieczeństwo wewnętrzne i porzadek publiczny jako sfera działania administracji publicznej, Lublin 2015, s. 29-46; M. Karpiuk, Pomoc społeczna jako instytucja umożliwiająca rodzinom przezwyciężanie trudnych sytuacji życiowych i jej miejsce w sferze bezpieczeństwa socjalnego, „Społeczeństwo i Rodzina” 2017, nr 1, s. 41-42; J. Kostrubiec, Status of a Voivodship Governor as an Authority Responsible for the Matters of Security and Public Order, „Barometr Regionalny” 2018, nr 5, s. 35-40; M. Karpiuk, Activities of the local government units in the scope of telecommunication, „Cybersecurity and Law” 2019, nr 1, s. 45. 
Należy podkreślić, że akcję ratowniczą organizuje i kieruje nią Państwowa Straż Pożarna (obowiązek ten wynika z art. 20 ust. 1 u.PSP), a nie wójt.

System ochrony przeciwpożarowej zbudowany jest w oparciu o instytucję zespolenia zarówno na szczeblu województwa, jak i powiatu, co jest bezpośrednio związane z miejscem Państwowej Straży Pożarnej w przestrzeni bezpieczeństwa ${ }^{21}$. Na powiatową administrację zespoloną składają się jednostki organizacyjne stanowiące aparat pomocniczy kierowników powiatowych służb, inspekcji i straży, co wynika z art. 33 b pkt 3 ustawy z dnia 5 czerwca 1998 r. o samorządzie powiatowym. Zwierzchnikiem w ramach zespolenia jest starosta, a nie wójt; do zadań komendanta powiatowego (miejskiego) Państwowej Straży Pożarnej należy organizowanie i prowadzenie akcji ratowniczej (art. 13 ust. 6 pkt 7 u.PSP).

Realizację przedsięwzięć mających na celu ochronę życia, zdrowia, mienia lub środowiska przed innym miejscowym zagrożeniem (powodzią) poprzez: 1) zapobieganie powstawaniu i rozprzestrzenianiu się innego miejscowego zagrożenia; 2) zapewnienie sił i środków do zwalczania innego miejscowego zagrożenia; 3) prowadzenie działań ratowniczych - Państwowa Straż Pożarna podejmuje niezwłocznie, gdy poweźmie stosowną informację, na polecenie kierownika jednostki ochrony przeciwpożarowej (np. PSP działającej w terenie), nie czekając na polecenie organu wykonawczego gminy jako organu zewnętrznego, spoza struktury organizacyjnej Państwowej Straży Pożarnej, który nie ma obowiązku kierowania takich poleceń do straży. W przeciwnym wypadku może się okazać, że Państwowa Straż Pożarna nie dopełnia ciążących na niej ustawowych obowiązków.

W konkluzji wypada jeszcze raz podkreślić, że proces myślowy sądu utrwalony w uzasadnieniu komentowanego wyroku budzi w naszej ocenie poważne wątpliwości. W żadnej mierze nie da się bowiem obronić metody orzekania, która opiera się na sztucznym zamykaniu tego procesu w granicach prawa karnego, którą to dziedzinę prawa sąd zdaje się traktować jako wyizolowaną z systemu prawa. Tak jak w sferze administracji publicznej istnieje potrzeba eliminowania zjawiska Polski „resortowej”, gdzie każdy minister realizuje swoją politykę (politykę danego działu administracji rządowej), w tym tworzy i stosuje prawo, nie zważając na działania innych ministrów, co prowadzi do izolowania od siebie poszczególnych gałęzi prawa, tak i w sferze wymiaru sprawiedliwości należy eliminować skłonność do dzielenia systemu prawa na ,prawo sądowe” i ,inne”.

${ }^{21}$ M. Karpiuk, Zadania i kompetencje zespolonej administracji rzadowej w sferze bezpieczeństwa narodowego Rzeczypospolitej Polskiej. Aspekty materialne i formalne, Warszawa 2013, s. 409. $\mathrm{Na}$ temat statusu organów administracji zespolonej w okresie międzywojennym por. J. Kostrubiec, Administracja ogólna w myśli prawniczej Drugiej Rzeczypospolitej, Warszawa 2019, s. 26-45. 


\section{BIBLIOGRAFIA}

\section{Literatura}

Aspekty prawne bezpieczeństwa narodowego RP. Część ogólna, red. W. Kitler, M. Czuryk, M. Karpiuk, Warszawa 2013.

Bożek M., Karpiuk M., Kostrubiec J., Walczuk K., Zasady ustroju politycznego państwa, Poznań 2012. Chmaj M., Ocena przepisów poselskiego projektu ustawy o zmianie ustawy - Kodeks wyborczy, Druk Sejmowy nr 3163.

Czuryk M., Bezpieczeństwo jako dobro wspólne, „Zeszyty Naukowe KUL” 2018, nr 3.

Czuryk M., Właściwość Rady Ministrów oraz Prezesa Rady Ministrów w zakresie obronności, bezpieczeństwa i porządku publicznego, Olsztyn 2017.

Czuryk M., Drabik K., Pieczywok A., Bezpieczeństwo człowieka w procesie zmian społecznych, kulturowych i edukacyjnych, Olsztyn 2018.

Czuryk M., Dunaj K., Karpiuk M., Prokop K., Bezpieczeństwo państwa. Zagadnienia prawne i administracyjne, Olsztyn 2016.

Czuryk M., Dunaj K., Karpiuk M., Prokop K., Prawo zarzadzania kryzysowego. Zarys systemu, Olsztyn 2016.

Czuryk M., Kostrubiec J., The legal status of local self-government in the field of public security, „Studia nad Autorytaryzmem i Totalitaryzmem” 2019, nr 1.

Dobkowski J., Kompetencja administracyjna, „Studia z Zakresu Nauk Prawnoustrojowych. Miscellanea" 2008, nr 1.

Dunaj K., Prokop K., Prawoznawstwo. Zagadnienia podstawowe, Warszawa 2017.

Karpiuk M., Activities of the local government units in the scope of telecommunication, „Cybersecurity and Law" 2019, nr 1.

Karpiuk M., Konstytucyjna właściwość Sejmu w zakresie bezpieczeństwa państwa, „Studia Iuridica Lublinensia” 2017, nr 4.

Karpiuk M., Miejsce samorządu terytorialnego w przestrzeni bezpieczeństwa narodowego, Warszawa 2014.

Karpiuk M., Ograniczenie wolności uzewnętrzniania wyznania ze względu na bezpieczeństwo państwa i porządek publiczny, „Przegląd Prawa Wyznaniowego” 2017, t. 9.

Karpiuk M., Pomoc społeczna jako instytucja umożliwiająca rodzinom przezwyciężanie trudnych sytuacji życiowych i jej miejsce w sferze bezpieczeństwa socjalnego, „Społeczeństwo i Rodzina” 2017, nr 1.

Karpiuk M., Position of County Government in the Security Space, „Internal Security” 2019, nr 1, DOI: https://doi.org/10.5604/01.3001.0013.5349.

Karpiuk M., Position of the Local Government of Commune Level in the Space of Security and Public Order, ,,Studia Iuridica Lublinensia” 2019, nr 2, DOI: https://doi.org/10.17951/sil.2019.28.2.27-39.

Karpiuk M., Prezydent Rzeczypospolitej Polskiej jako organ stojący na straży bezpieczeństwa państwa, „Zeszyty Naukowe AON” 2009, nr 3.

Karpiuk M., Ubezpieczenie społeczne rolników jako element bezpieczeństwa społecznego. Aspekty prawne, „Międzynarodowe Studia Społeczno-Humanistyczne. Humanum” 2018, nr 2.

Karpiuk M., Właściwość wojewody w zakresie zapewnienia bezpieczeństwa i porzadku publicznego oraz zapobiegania zagrożeniu życia i zdrowia, „Zeszyty Naukowe KUL” 2018, nr 2.

Karpiuk M., Zadania administracji publicznej w zakresie bezpieczeństwa społecznego dotyczace wspierania rodziny przeżywającej trudności w wypetnianiu funkcji opiekuńczo-wychowawczych i odnoszace się do systemu pieczy zastępczej, „Społeczeństwo i Rodzina” 2018, nr 3.

Karpiuk M., Zadania i kompetencje zespolonej administracji rządowej w sferze bezpieczeństwa narodowego Rzeczypospolitej Polskiej. Aspekty materialne i formalne, Warszawa 2013. 
Karpiuk M., Prokop K., Sobczyk P., Ograniczenie korzystania z wolności i praw człowieka i obywatela ze względu na bezpieczeństwo państwa i porządek publiczny, Siedlce 2017.

Karpiuk M., Szczęch N., Bezpieczeństwo narodowe i międzynarodowe, Olsztyn 2017.

Kostrubiec J., Administracja ogólna w myśli prawniczej Drugiej Rzeczypospolitej, Warszawa 2019.

Kostrubiec J., Status of a Voivodship Governor as an Authority Responsible for the Matters of Security and Public Order, „Barometr Regionalny” 2018, nr 5.

Lis W., Bezpieczeństwo wewnętrzne i porządek publiczny jako sfera działania administracji publicznej, Lublin 2015.

Matczak M., Kompetencja, [w:] System prawa administracyjnego, red. M. Matczak, R. Hauser, Warszawa 2015.

Pieczywok A., Działania społeczne w sferze bezpieczeństwa wewnętrznego, Lublin 2018.

Szczęch N., [w:] Administracja publiczna i prawo administracyjne w zarysie, red. M. Karpiuk, J. Kowalski, Warszawa-Poznań 2013.

Tyrawa D., Gwarancje bezpieczeństwa osobistego w polskim administracyjnym prawie drogowym, Lublin 2018.

\section{Orzecznictwo}

Wyrok NSA z dnia 21 sierpnia 2018 r., I GSK 2276/18, LEX nr 2558172.

Wyrok TK z dnia 18 marca 2017 r., K 8/07.

Wyrok WSA z dnia 9 października 2008 r., II SA/Rz 506/08, LEX nr 505412.

Wyrok WSA z dnia 18 listopada 2009 r., IV SA/Gl 327/09, LEX nr 589404.

Wyrok WSA z dnia 16 lipca 2014 r., IV SA/Po 507/14, LEX nr 1498465.

Wyrok WSA z dnia 13 kwietnia 2017 r., II SA/G1 124/17, LEX nr 2278648.

Wyrok WSA z dnia 24 października 2017 r., III SA/Kr 397/17, LEX nr 2381414.

Wyrok WSA z dnia 14 listopada 2018 r., II SA/Go 713/18, LEX nr 2582085.

\section{SUMMARY}

The tasks concerning public safety and order, as well as flood protection, have been assigned by the legislator to the executive body of the municipality. Task standards alone, however, cannot constitute a sufficient legal basis for determining obligations of the authority within this scope, especially in the context of criminal-law assessment of their non-fulfillment. Such assessment requires a precise setting of the content of the competency standards since only such norms can establish obligations of the authority and constitute an instrument for carrying out the tasks. The legislator should clearly indicate the obligations incumbent on the authority, and the criminal court should determine the ones which have not been fulfilled giving a specific provision of law requiring a specific action.

Keywords: expiry of the mandate of the vogt; non-compliance with the obligations; crisis management; flood 